\title{
THE INFLUENCE OF LAND USE IN CONTROLLING POTENTIAL DAMAGE IN THE UPPER BRANTAS RIVER BASIN
}

\author{
Sri Harini \\ Departement of Mathematics Faculty Sains and Technologi \\ State University of Maulana Malik Ibrahim Malang \\ Email : sriharini21@yahoo.co.id
}

Keywords : land use, land capability, erosion, forest, soil, river basin

\begin{abstract}
The Upper Brantas river basin (DAS Brantas Hulu) has natural resources such as forests, soil and water potential. If well managed will provide great benefits and can improve the welfare of society. Changes in land use are not well planned and the impact of human activities that are not true cause a reduction in water catchment areas as a causing of erosion in the Upper Brantas river basin. This study aims to gain an overview of land use, land capability and potential erosion in the Upper Brantas river basin as a basis for policy making in environmentally sound watershed management.
\end{abstract}

\section{Introduction}

Along with population growth and the development of human civilization, discovery and use of technology, as well as the dynamics of development, its the impact of the control of land use is increasingly weak and eventually lead to the complexity of the problems. Land that once the forest has been functioning as media cultivation (agriculture) and housing uncontrolled. If this condition is left, then will have an imfact to the reduction of water catchment areas [1]. Various ways to handle the critical area has been done by the government, such as through reforestation and afforestation. However, its success is still small (only $21 \%$ ). This might be due to lack of precise technology used, or the condition of the land has not been studied carefully, or because the technology is not fully is implemented. In addition, as a result of reviews these management changes, the forests in the watershed today are experiencing a lot of damage and conversion to agricultural land, housing and others. Changes in forest conversion is to start decreasing number of forests in this location, reduced water source, erosion layer of fertile soil, the incidence of landslides, silting of rivers and ultimately bring the impact of changes in the direction of critical land. Several previous studies as the basis of this study conducted by [2] mapping of the forest land use taking into account the data spatial of plants and land contours. In the field of geology [3] look for the relationship between the erosion that occurs along the river with variable goemorfologi using Geographically Weighted Linear Regression models (GWLR). GWLR model GWLR is deemed appropriate because was able to influence the geographic location of the upstream, midstream and downstream river. [4] states that the shape of a watershed affects the shape of hydrograph characteristics. DAS has specific characteristics and is closely related to the main elements such as soil type, land use , topography, slope and length that the shape of a watershed affects the shape of hydrograph characteristics. Characteristics of the watershed can respond precipitation that falls in place and potentially influence the size evapotranpirasi, infiltration, runoff, soil water content and flow of the river [5]. [6] examined The Leon River Watershed (LRW) in Central Texas is a benchmark and special emphasis watershed within the conservation effects assessment project located in central texas. Model simulations from 1977 through 2006 were used to evaluate six manure nutrient management scenarios that reflect realistic strategies that could be employed to reduce nutrient and sediment loadings in the LRW. Due to the presence of several dairies and a relatively large number of cows, special attention within this watershed is necessary to determine beneficial adjustments that can be made to protect water quality. The nutrient management scenarios analyzed reduced total nitrogen $(\mathrm{N})$ and total phosphorus $(\mathrm{P})$ loading in nearly all of the subbasins. Total $\mathrm{N}$ and total $\mathrm{P}$ loading was also reduced at the watershed scale; sediment load reduction was minor due to effective 
management measures already existing within the LRW. Model simulations conducted over a 30year period for six manure management scenarios indicated that both total $\mathrm{N}$ and total $\mathrm{P}$ can be significantly reduced by employing additional nutrient strategies. This is the case whether the nutrients are removed from the immediate vicinity of the dairy or are transported outside of the watershed.

\section{Methods}

This research used a descriptive quantitative approach. Where the analysis data in diskriptif, so as to explain and describe the conditions of research objects clearly. In this study used data on the Upper Brantas river basin [7].

\section{Results And Discussion}

In this study the variables used to measure the effect of changes in land use include: the length of the river, slope, sub-watershed area and discharge. The results of the data analysis can be described as follows:

Tabel 1. Descriptive Statistics: long river (m), slope (\%), area drainase ha), debit $\left(\mathrm{m}^{3} / \mathrm{dt}\right)$

\begin{tabular}{|l|cccccccc|}
\hline Variable & Total & & & & & & & \\
& Count & $\mathrm{N}$ & $\mathrm{N}^{*}$ & Mean & SE Mean & StDev & Variance & Sum \\
\hline Long river(m) & 7 & 7 & 0 & 9725 & 2264 & 5989 & 35869350 & 68078 \\
Slope (\%) & 7 & 7 & 0 & 0.438 & 0.151 & 0.400 & 0.160 & 3.066 \\
Drainage area(ha) & 7 & 7 & 0 & 93805 & 18029 & 47699 & 2275205804 & 656637 \\
Debit (m ${ }^{3} /$ dtk) & 7 & 7 & 0 & 36.77 & 4.47 & 11.83 & 139.94 & 257.39 \\
\hline
\end{tabular}

Table 1 can be described as follows the length main river that traversed watershed (DAS) along the Upper Brantas river basin is 68078 meters with an average length of river for each observation point is 9725 meters. The average slope of the watershed was $43.8 \%$. This means that the Upper Brantas river basin is an area that has a high slope in the form of mountain slopes and cliffs. Total drainage area is 656637 ha, with an average drainage area (spread of water) of 93805 ha of land in the watershed through the Upper Brantas. The amount of water discharge in the Brantas river basin during the wet months at $257.39\left(\mathrm{~m}^{3} / \mathrm{s}\right)$, with an average discharge of water that can be accommodated in the Upper Brantas river basin is at $36.77\left(\mathrm{~m}^{3} / \mathrm{s}\right)$.

As an illustration the average discharge of water in the Brantas river basin can still be said to be at a safe level or not can be seen from the graph below :

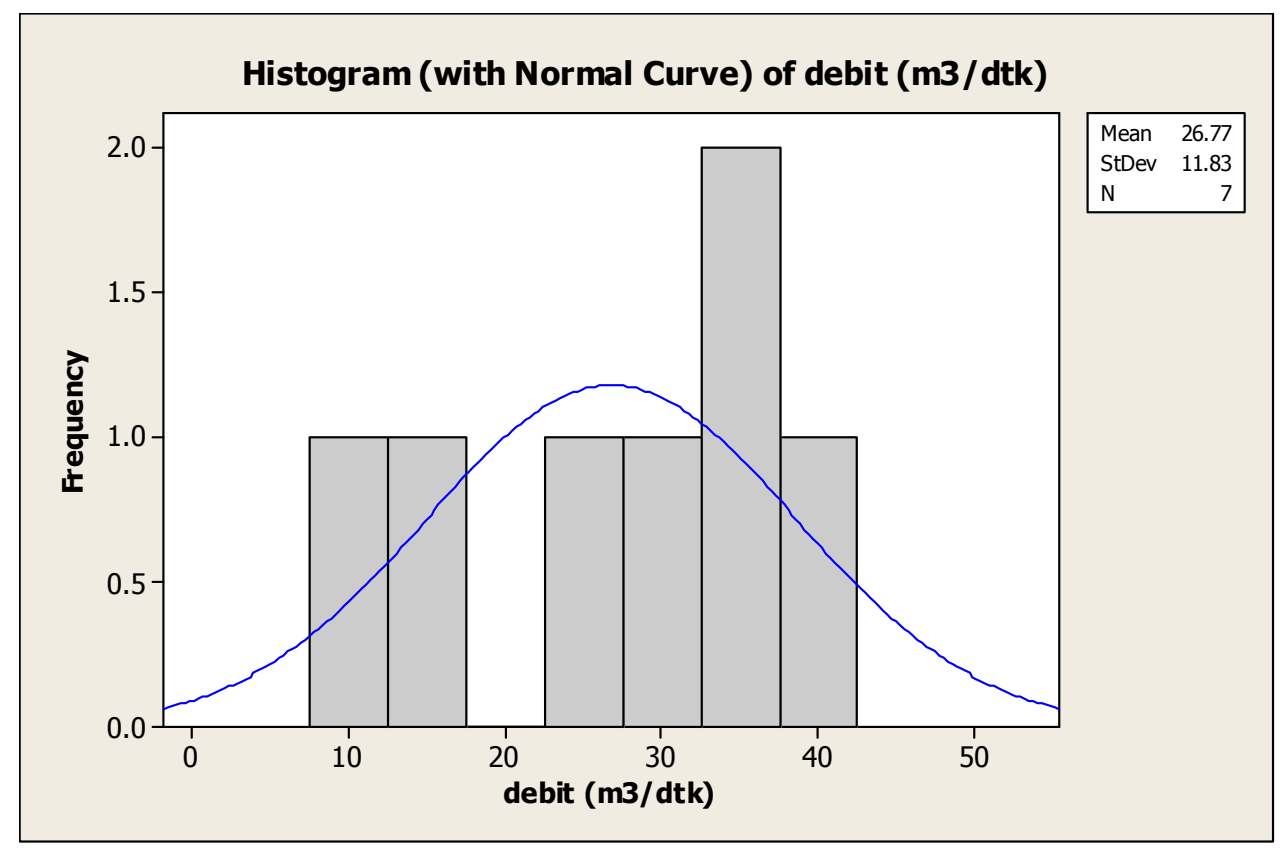

Figure 1 Histogram of the distribution of water discharge from the sevent point observation 
Plot the graph in Figure 1 shows that the Upper Brantas river basin is said to dangerous levels if the average water discharge (peak discharge) at the level of $35\left(\mathrm{~m}^{3} / \mathrm{s}\right)$. Looking at the average water discharge generated at $36.77\left(\mathrm{~m}^{3} / \mathrm{s}\right)$, it can be stated that the Upper Brantas river basin water discharge is approaching dangerous levels (categories of disaster preparedness). It required serious treatment of all parties to the managing the Upper Brantas river basin.

Based on the results of field research, these conditions are common in the Upper Brantas river basin, which generally has a steep slope with a slope ranging from $40-60 \%$. As an illustration based on the criteria of critical land areas are protected by virtue of the Director General of Reforestation and Land Rehabilitation Department of Forestry number 412/V-CTR/1997 [8] obtained the critical land area and the distribution of land use in the Upper Brantas river basin can be seen in Table 2 and Table 3 below :

Table 2 Clasification Criticality of land in the Upper Brantas Watershed

Source : Analysis of spatial data with GWR (2012)

\begin{tabular}{llcc}
\hline No & Criticality of land & Area (Ha) & \% \\
\hline 1 & Non-critical & 20.17 & 0.12 \\
2 & potensial critical & 4155.37 & 23.96 \\
3 & Rather critical & 4351.29 & 25.09 \\
4 & Critical & 6070.40 & 35.00 \\
5 & Very critical & 2746.56 & 15.84 \\
\hline & Total & $\mathbf{1 7 3 4 3 . 8 1}$ & $\mathbf{1 0 0}$
\end{tabular}

Table 2 shows that the data criticality class of land in the Upper Brantas river basin is divided into 5 classes which include non-critical $0.12 \%$, potentially critical $23.96 \%$, rather critical $25.09 \%$, critical $35 \%$ and very critical $15.84 \%$. From these results it can be concluded that the DAS Brantas Hulu is at a critical level. Land criticality conditions are closely related to the distribution of land use (Table 3).

Table 3 Distribution of land use in the Upper Brantas river basin

\begin{tabular}{clcr}
\hline \multirow{2}{*}{ No } & Land Use & \multicolumn{2}{c}{ Area } \\
& Forest & 7030.217 & \% area \\
\hline 1 & Moor & 5117.934 & 29.89 \\
3 & Garden & 3680.577 & 15.73 \\
4 & Rainfed rice fields & 3252.867 & 13.83 \\
5 & Shrublands & 1711.413 & 7.28 \\
6 & Settlement & 1146.261 & 4.86 \\
7 & Irrigation Rice Field & 944.293 & 4 \\
8 & Freshwater & 344.134 & 1.44 \\
9 & Grassland wasteland & 286.334 & 1.22 \\
10 & Sand land & 6.113 & 0.03 \\
11 & Pond & 2.482 & 0.01 \\
\hline
\end{tabular}

Source : Analysis of spatial data with GWR (2012)

Results Table 3 shows the distribution of land use in the Upper Brantas river basin is only $29.89 \%$ for the use of forest land and the remaining ones to-ends meet human without thinking element of the balance of nature. Land use policies to assist the government in identifying the condition of the land in each sub-watershed Brantas.

Based on the results of Tables 2 and 3 show that the critical condition of the land and the distribution of land use influence changes on soil erosion class. The more critical the area, the greater the rate of erosion in the area. (Table 4) . 


\begin{tabular}{|c|c|c|c|}
\hline No & Criticality of land & Area (Ha) & $\%$ \\
\hline 1 & light & 3867.85 & 22.30 \\
\hline 2 & medium & 2382.74 & 13.74 \\
\hline 3 & weight & 2918.77 & 16.83 \\
\hline 4 & very weight & 8174.43 & 47.13 \\
\hline & Total & 17343.81 & 100 \\
\hline
\end{tabular}

Source : Analysis of spatial data with GWR (2012)

Based on reviews these results it can be shown that the condition of the soil around the Upper Brantas river basin, already at a critical level and is very critical. Therefore need intensive efforts and assistance of the various parties involved (PT Perhutani, local government and community) in providing public awareness of the importance of conservation of natural resources (SDA) in the Upper Brantas river basin according to function properly.

\section{Summary}

Based on the results and discussion, it can be concluded that more than $60 \%$ of land in the Upper Brantas river basin is in a class of heavy erosion. This is due to the increasing number of forest damage around the Brantas river basin upstream region, so that when the high rainfall will further increase of the rate of erosion in the region. This result is supported on the distribution of land uses in the Upper Brantas river basin only $29.89 \%$ for the forest and the rest is used by humans to the ends meet without thinking elements of the balance of nature.

\section{References}

[1] Suripin. (2001). Management of Soil and Water Resources. Andi Offset, Yogyakarta.

[2] Mennis, J. (2006), Mapping the Results of Geographically Weighted Regression, The Cartographic Journal, Vol. 43, No. 2, hal. 171-179.

[3] Atkinson, P.M, German, S.E, Sear, D.A dan M.J, Clark. (2003), Exploring the Relations Between Riverbank Erosion and Geomorphological Controls Using Geographically Weighted Logistic Regression, Journal of Geographical Analysis, Vol. 35 No. 1, The Ohio State University.

[4] Zhang, L dan Gove, J.H. (2005), Spatial Assessment of Model Errors from Four Regression Techniques, Journal of Forest Science, Vol. 51, No. 4, hal. 334-346.

[5] Asdak, C. (2002). Hydrology and Watershed Management. Gajah Mada University Press. Yogyakarta.

[6] C.G. Rossi, T.J. Dybala, D.N. Moriasi, J.G. Arnold, C. Amonett, and T. Marek. (2012). Manure Nutrient Management Effects In The Leon River Watershed. Journal of Soil and Water Conservation ; 67(3): 147-157.

[7] Murtiono, U.H. (2001), Technical Guidelines for Measurement and Calculation Parameters Morphometry watershed, Jurnal Info DAS, no. 10, 2001, Forestry Research and Development Agency, BTP DAS Surakarta.

[8] Balai KSDA East Java. (2006). Data Statistics Balai KSDA in East Java, Department of Forestry, Jakarta. 
Advances in Green Science, Engineering and Built Environment

10.4028/www.scientific.net/AMM.747

The Influence of Land Use in Controlling Potential Damage of the Upper Brantas River Basin 10.4028/www.scientific.net/AMM.747.298 